Mineralogical Journal, Vol. 4, No. 4, PP. 245-274, Feb., 1965

\title{
THERMOCHEMICAL STABILITY OF NINGYOITE
}

\author{
TADASHI MUTO \\ Atomic Fuel Research Laboratory, Atomic Fuel Corporation, \\ Tokai, Ibaraki
}

\begin{abstract}
The solubilities of ningyoite, autunite, and hydrogen-autunite, all synthetic except autunite, were measured mainly at $25^{\circ}$ and $100^{\circ} \mathrm{C}$ by immersing them in water with $\mathrm{pH}$ ranging from 0 to 6 . Equilibrium constants of the dissolution reactions of the minerals were obtained by estimating activities of the concerning ions with the aid of the Debye-Hückel limiting law from the uranium concentrations and the $\mathrm{pH}$ values of the solutions. The standard free energies of formation of the minerals were then calculated from the equilibrium constants. The values are $-948 \mathrm{Kcal}$ for ningyoite $\mathrm{CaU}\left(\mathrm{PO}_{4}\right)_{2}$. $2 \mathrm{H}_{2} \mathrm{O},-1728 \mathrm{Kcal}$ for autunite $\mathrm{Ca}\left(\mathrm{UO}_{2}\right)_{2}\left(\mathrm{PO}_{4}\right)_{2} \cdot 10 \mathrm{H}_{2} \mathrm{O}$, and $-1598 \mathrm{Kcal}$ for hydrogen-autunite $\mathrm{H}_{2}\left(\mathrm{UO}_{2}\right)_{2}\left(\mathrm{PO}_{4}\right)_{2} \cdot 10 \mathrm{H}_{2} \mathrm{O}$ with probable errors of $\pm 2 \mathrm{Kcal}$. The standard enthalpy of formation of ningyoite was evaluated to be -1035 $\pm 5 \mathrm{Kcal}$ from the equilibrium constants at $25^{\circ}$ and $100^{\circ} \mathrm{C}$.

Stability fields of some uranium minerals in the forms of oxide, carbonate, sulphate, and uranate in addition to the three minerals were considered in Eh-pH diagrams constructed by using the above free energy values together with the available values of the relating compounds and ions. Stability of ningyoite in comparison with uraninite was estimated by examining chemical equilibria of some reactions including them. Ningyoite stably precipitates at lower temperatures around $25^{\circ} \mathrm{C}$ under neutral or acidic conditions with phosphorus activity around or above $10^{-8}$, which seems to be similar to that in supergenic waters, while at higher temperatures around $100^{\circ} \mathrm{C}$, only under weakly or moderately acidic conditions with high phosphorus activity around or above $2 \times 10^{-7}$. The conditions of the ore solution in the uranium deposits around the Ningyô-tôgé area were discussed by examining equilibrium relations among the paragenetically occurring minerals including ningyoite. The reason why ningyoite has never been found in other uranium ores with high phosphorus content, e.g. phosphorite, is explained from the limitation on $\mathrm{pH}$ and temperature for the formation of the mineral.
\end{abstract}




\section{Introduction}

Ningyoite (Ca, U, R.E.) $\mathrm{P}(\mathrm{O}, \mathrm{OH})_{4} \cdot 0.5-1 \mathrm{H}_{2} \mathrm{O}$ is the principal uranium ore mineral in all the uranium deposits around the Ningyô-tôgé area-Ningyô-tôgé mine and Tôgô mine, but has never been found in the other deposits in the world. Fisher and Meyrowitz (1962) stated in their description of a new mineral brockite, a hexagonal rhabdophane-type phosphate mineral of calcium, thorium, and rare earths, that a hexagonal mineral from Cornwall, apparently the uranium analogue of brockite was under investigation by members of the Geological Survey of Great Britain. This is perhaps the only description suggesting the occurrence of a ningyoite-like mineral, though it differs from ningyoite in the crystal system.

Since it has been recognized by the writer that ningyoite is stable in spite of its structural similarity with a metastable phosphate mineral of rare earths, rhabdophane (Muto, 1962), it is to be questioned why it has never been found in other uranium ores, even in those containing unusually high phophorus content such as phosphorite. Results of the syntheses of ningyoite have not given a definite answer to this question. Synthetic experiments of a mineral are often incompatible with its modes of occurrence in nature, because of such differences between them as duration of a reaction and salt concentrations in a solution. Therefore, thermochemical examination of ningyoite was carried out to supplement the synthetic experiments, and the stability relations of ningyoite with other relating minerals were presented in this paper with the use of thermochemical data calculated from solubilities at different temperatures.

\section{Experimental}

Samples

A ningyoite sample was synthesized from uranous chloride and monobasic calcium phosphate solution. The $\mathrm{UCl}_{4}$ solution of 0.03 moles taken from an intermediate product of the refining process in the 
Tokai Refinery was mixed with solution containing 0.06 moles of $\mathrm{Ca}\left(\mathrm{H}_{2} \mathrm{PO}_{4}\right)_{2}$, and the resulting slurry solution was boiled for 10 minutes. After cooling in nitrogen atmosphere the $\mathrm{pH}$ of the solution was adjusted up to 6.0 with $\mathrm{NaOH}$. The gelatinous precipitate was centrifuged, washed with water twice, and then transferred into Morey bombs with water. The bombs were heated at $200^{\circ} \mathrm{C}$ for three days. The $\mathrm{pH}$ values of the water before and after heating were 6.40 and 2.70 respectively. The precpitate was centrifuged, washed with $(1+5) \mathrm{HCl}$, then with water, and dried in a desiccator filled with nitrogen... All the water used for the synthesis and for the solubility measurements of ningyoite had been distilled through vigorous boiling and cooling in nitrogen to remove dissolved oxygen. The synthetic product (Cup200) was identified by $X$-ray means with natural ningyoite. The chemical composition of the Cup-200 was analyzed to be $\mathrm{Ca}_{1.23} \mathrm{U}_{0.77}$ $\left[\mathrm{PO}_{3.54}(\mathrm{OH})_{0.46}\right]_{2} \cdot 1.8 \mathrm{H}_{2} \mathrm{O}$ (Analyst; $\mathrm{S}$. Takani, Atomic Fuel Corporation), which is a little higher in the calcium content than in the natural mineral, $\mathrm{Ca}_{1.0} \mathrm{U}_{0.8}$ R. $\mathrm{E}_{\cdot 0.2}\left[\mathrm{P}(\mathrm{O}, \mathrm{OH})_{4}\right]_{2} \cdot 1-2 \mathrm{H}_{2} \mathrm{O}$ (Muto, 1962). Besides Cup-200, three synthetic ningyoite samples: Cup-E2-150, $\mathrm{Ca}_{1.04} \mathrm{U}_{0.96}$ $\left[\mathrm{PO}_{3.92}(\mathrm{OH})_{0.08}\right]_{2} \cdot n \mathrm{H}_{2} \mathrm{O}$; Cup-E3-150, $\mathrm{Ca}_{1.08} \mathrm{U}_{0.92}\left[\mathrm{PO}_{3.84}(\mathrm{OH})_{0.16}\right]_{2} \cdot n \mathrm{H}_{2} \mathrm{O}$; and Aup-D-130, where the chemical formulae were calculated from the analytical values listed in the reference (Muto, 1962), were also used for the solubility measurements for comparison.

Solubility measurements were also carried out for autunite and synthetic hydrogen-autunite (Denoted as $\mathrm{H}$-autunite in the following). Autunite is from the Daybreak mine, Wash., U.S. A., and was carefully separated from admixing uraninite and gangue minerals. $\mathrm{H}$ autunite was synthesized by mixing phosphoric acid and uranyl chloride solution both in $1 \mathrm{mM}$ concentrations.

\section{Solubility measurements}

A number of solubility measurements of the above mentioned minerals were carried out in order to find equilibrium values at different temperatures. A small amount of the specimens (a few to 
$100 \mathrm{mg}$ according to the $\mathrm{pH}$ of a solution) were put in $250 \mathrm{ml}$ polyethylene bottles with $200 \mathrm{ml}$ of water $(20$ to $50 \mathrm{ml}$ at lower $\mathrm{pH}$ ranges in $100 \mathrm{ml}$ bottles) of various $\mathrm{pH}$ values ranging from 0 to 6 . After sealed, the bottles were immersed in a thermostatic tank with thermoelements or in a water bath in occasional shaking. After certain periods the bottles were opened. Supernatant solutions were decanted through double sheets of No. $5 c$ filter paper, which were mounted on a warm-water jacketed funnel except in the case at $25^{\circ} \mathrm{C}$, after the $\mathrm{pH}$ was measured with a Horbia $\mathrm{M}-3 \mathrm{pH}$ meter using normal or high temperature glass electrodes. The filtered solutions were analyzed for uranium concentrations either by spectrophotometry using 4-(2-pyridylazo)-resorcinol as a color developing reagent or by fluorimetry (Analysts; I. Wachi and O. Hirano, Atomic Fuel Corporation).

First, the time necessary to equilibrate the dissolution reactions at $25^{\circ} \mathrm{C}$ was examined at $\mathrm{pH}$ about 3 for ningyoite and autunite. It was found from the experiments made with working periods of 1,3 , 9,30 and 90 days that ningyoite reaches an equilibrium in less than 3 days, while autunite needs 9 days, though about $90 \%$ of the equilibrium solubility is attained in three days. Thus, in the later experiments, the immersion times were decided as 5 days at $25^{\circ} \mathrm{C}, 4$ days at $50^{\circ}$ and $75^{\circ} \mathrm{C}$, and 3 days at $100^{\circ} \mathrm{C}$.

The experiments were done mostly at $25^{\circ}$ and $100^{\circ} \mathrm{C}$, and only for comparison at $50^{\circ}$ and $75^{\circ} \mathrm{C}$. The $\mathrm{pH}$ of water was adjusted by hydrochloric acid from 0 to 6 at intervals from 0.5 to 1.0. Perchloric acid, which is generally used for thermochemical work, was not employed because it might cause tetravalent uranium to be oxidized to sexivalent. In the case of ningyoite, a trace amount of stannous chloride or sodium sulphite was added as an antioxidant. Some of the results obtained are shown in Fig. 1 and Table 1, where data of autunite and $\mathrm{H}$-autunite at $100^{\circ} \mathrm{C}$ are omitted as temperature factors of sexivalent uranium ions have been known only partly. The undissolved residues were examined by means of an X-ray diffractometer. It was found that ningyoite never changes its diffraction pattern even 
after immersed in a strong acid solution at $100^{\circ} \mathrm{C}$, while autunite is transformed into $\mathrm{H}$-autunite or its analogues of different water contents in acidic solution by a cation exchange reaction,

$$
\mathrm{Ca}\left(\mathrm{UO}_{2}\right)\left(\mathrm{PO}_{4}\right)_{2} \cdot 10 \mathrm{H}_{2} \mathrm{O}+2 \mathrm{H}^{+}=\mathrm{H}_{2}\left(\mathrm{UO}_{2}\right)\left(\mathrm{PO}_{4}\right)_{2} \cdot 10 \mathrm{H}_{2} \mathrm{O}+\mathrm{Ca}^{2+}
$$

The lowest $\mathrm{pH}$ limits where autunite can exist stably without additional calcium other than that dissolved from itself were found to be about 3 at $25^{\circ} \mathrm{C}$ and 4 at $100^{\circ} \mathrm{C}$. This corresponds to the fact that the solubility of autunite coincides with that of $\mathrm{H}$-autunite in acidic solution as shown in Fig. 1.

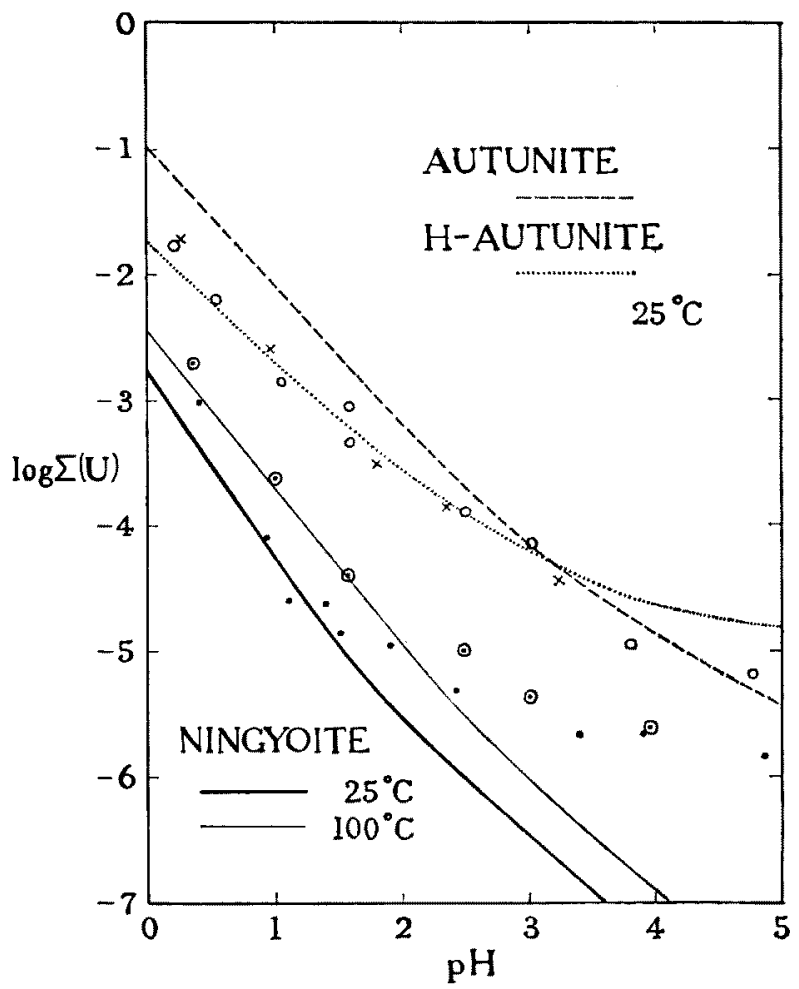

Fig. 1. Solubilities of ningyoite, autunite, and hydrogen-autunite.

The complex ions with $\mathrm{Cl}^{-}$or $\mathrm{H}_{3} \mathrm{PO}_{4}$ have not been considered for these theoretical solubility curves. 
At least three phases of mono-hydrogen uranyl phosphate $\mathrm{HUO}_{2}$ $\mathrm{PO}_{4} \cdot n \mathrm{H}_{2} \mathrm{O}$ were recognized by means of $\mathrm{X}$-ray diffractometry. Their basal spacings were $8.6,9.1$ and $10.5 \AA$. The $8.6 \AA$ phase was identical with $\mathrm{UO}_{2} \mathrm{HPO}_{4} \cdot 2 \mathrm{H}_{2} \mathrm{O}$ in its powder data (Dunn, 1956) and the $9.1 \AA$ phase was almost identical with $\mathrm{H}$-autunite $\mathrm{H}_{2}\left(\mathrm{UO}_{2}\right)_{2}\left(\mathrm{PO}_{4}\right)_{2} \cdot 8 \mathrm{H}_{2} \mathrm{O}$ described by Frondel (1958), but the $10.5 \AA$ phase did not produce a pattern conformable to any of the available data of uranyl phosphate compounds. The $8.6 \AA$ phase is generally stable below pH 1 at $25^{\circ}$ and 2 at $100^{\circ} \mathrm{C}$, the $9.1 \AA$ phase perhaps from 1 to 2 at $25^{\circ}$ and 2 to 3.5 at $100^{\circ} \mathrm{C}$, and the $10.5 \AA$ phase appears in less acidic conditions. Transition from one of the three phases to the others is easy and reversible. Occasionally the $11.0 \AA$ and $8.8 \AA$ phases were recognized with other phases, but their stable $\mathrm{pH}$ ranges were not decided. It can be stated on these mono-hydrogen uranyl phosphates that the shorter the basal spacing of a phase is, the less is its water content, and they are the more stable, the more acidic is the solution and the higher the temperature.

\section{Evaluation of thermochemical values}

The solubility measurement of ten produces an experimental value inconsistent with thermochemical calculation even when special care is taken to give sufficient time for equilibration and reasonably accurate values of activity coefficients. In most of the cases the discrepancy can be attributed to an unknown complex ion or to colloidal dispersion, but occásionally to a surface complex on the solid or to an incongruent dissolution, as seen for example in the case of hydroxyl apatite (Deitz et al., 1964). This was the reason why the solubilities of the minerals under consideration were measured in a comparatively wide range of $\mathrm{pH}$.

Ningyoite, autunite, and $\mathrm{H}$-autunite are dissolved according to the following representative equations, expressed in ideal chemical formulae, 
$\mathrm{CaU}\left(\mathrm{PO}_{4}\right)_{2} \cdot 2 \mathrm{H}_{2} \mathrm{O}+6 \mathrm{H}^{+}=\mathrm{Ca}^{2+}+\mathrm{U}^{4+}+2 \mathrm{H}_{8} \mathrm{PO}_{4}+2 \mathrm{H}_{2} \mathrm{O} \quad \ldots \ldots \ldots \ldots \ldots(2)$,

$\mathrm{Ca}\left(\mathrm{UO}_{2}\right)_{2}\left(\mathrm{PO}_{4}\right)_{2} \cdot 10 \mathrm{H}_{2} \mathrm{O}+6 \mathrm{H}^{+}=\mathrm{Ca}^{2+}+2 \mathrm{UO}_{2}^{2+}+2 \mathrm{H}_{3} \mathrm{PO}_{4}+10 \mathrm{H}_{2} \mathrm{O} \cdots(3)$, and $\mathrm{H}_{2}\left(\mathrm{UO}_{2}\right)_{2}\left(\mathrm{PO}_{4}\right)_{2} \cdot 10 \mathrm{H}_{2} \mathrm{O}+4 \mathrm{H}^{+}=2 \mathrm{UO}_{2}^{2+}+2 \mathrm{H}_{3} \mathrm{PO}_{4}+10 \mathrm{H}_{2} \mathrm{O} \cdots \cdots \cdots(4)$.

If $K_{2}, K_{3}$ and $K_{4}$ are the equilibrium constants of equations (2), (3) and (4) respectively, as the activities of the solid and water can be regarded as unity, and $\mathrm{pH}$ is defined as $-\log \left[\mathrm{H}^{+}\right]$, relations hold as follows,

$$
\begin{aligned}
& \log K_{2}=\log \left[\mathrm{Ca}^{2+}\right]+\log \left[\mathrm{U}^{4+}\right]+2 \log \left[\mathrm{H}_{3} \mathrm{PO}_{4}\right]+6 \mathrm{pH} \cdots \cdots \cdots(2-1), \\
& \log K_{3}=\log \left[\mathrm{Ca}^{2+}\right]+2 \log \left[\mathrm{UO}_{2}^{2+}\right]+2 \log \left[\mathrm{H}_{3} \mathrm{PO}_{4}\right]+6 \mathrm{pH} \cdots \cdots(3-1),
\end{aligned}
$$

and $\quad \log K_{4}=2 \log \left[\mathrm{UO}_{2}^{2+}\right]+2 \log \left[\mathrm{H}_{3} \mathrm{PO}_{4}\right]+4 \mathrm{pH}$

where activity of $X$ is denoted by $[X]$.

Ionic species of phosphate and uranium $(I V, V I)$

Equations (2), (3) and (4) are applicable only to the dissolutions within limited $\mathrm{pH}$ ranges, because phosphoric acid and uranium can take various ionic forms which are determined by $\mathrm{pH}$ and $\mathrm{Eh}$ of the solutions and concentrations of uranium, phosphorus, and other ions.

Phosphoric acid mainly takes the forms of $\mathrm{H}_{3} \mathrm{PO}_{4}, \mathrm{H}_{2} \mathrm{PO}_{4}^{-}, \mathrm{HPO}_{4}^{2-}$ and $\mathrm{PO}_{4}^{3-}$ in an aqueous solution;

$$
\begin{aligned}
& \mathrm{H}_{3} \mathrm{PO}_{4}=\mathrm{H}_{2} \mathrm{PO}_{4}^{-}+\mathrm{H}^{+} \\
& \mathrm{H}_{2} \mathrm{PO}_{4}^{-}=\mathrm{HPO}_{4}^{2-}+\mathrm{H}^{+}
\end{aligned}
$$

and

$$
\mathrm{HPO}_{4}^{2-}=\mathrm{PO}_{4}^{2-}+\mathrm{H}^{+}
$$

Polymerized ions such as $\mathrm{H}_{2} \mathrm{P}_{2} \mathrm{O}_{7}^{2-}$ exist in a considerable amount only if the phosphorus concentration is high, but these can be neglected in the present case. A complex of phosphoric acid with tetravalent uranium has not been known, while a few complexes with sexivalent uranium have been reported: $\mathrm{UO}_{2} \mathrm{H}_{2} \mathrm{PO}_{4}^{+}, \mathrm{UO}_{2}\left(\mathrm{H}_{2} \mathrm{PO}_{4}\right)_{2}$ and $\mathrm{UO}_{2}\left(\mathrm{H}_{2} \mathrm{PO}_{4}\right)_{2}$. $\mathrm{H}_{3} \mathrm{PO}_{4}$. (Thamer, 1957). The first complex might take part in the total phosphate in the solution of this experiment, especially in the case where the concentrations of phosphate and uranyl ions are high, 
while the latter two complexes are not considered to have existed in any significant amount. The formation constant of the former was determined 15.5 by Thamer $(1957)$ at $25^{\circ} \mathrm{C}$. Thus,

$$
\log \left[\mathrm{UO}_{2}\left(\mathrm{H}_{2} \mathrm{PO}_{4}\right)^{+}\right]=\log \left[\mathrm{UO}_{3}^{2+}\right]+\log \left[\mathrm{H}_{3} \mathrm{PO}_{4}\right]+\mathrm{pH}+1.19 \ldots \ldots(8) \text {. }
$$

Only two ionic species of tetravalent uranium, $\mathrm{U}^{4+}$ and $\mathrm{UOH}^{3+}$, related to each other by the equation,

$$
\mathrm{U}^{4+}+\mathrm{H}_{2} \mathrm{O}=\mathrm{UOH}^{3+}+\mathrm{H}^{+}
$$

are given thermodynamical data. There are many papers reporting on the formation constant of the $\mathrm{UOH}^{3+}$ ion, but the thermodynamic values given in the table of N.B.S., U.S. A. (Rossini et al., 1952) were used in this study. More hydrated uranous ions such as $\mathrm{UO}^{2+}$ or $\mathrm{U}(\mathrm{OH})_{2}^{2+}$ and $\mathrm{U}(\mathrm{OH})_{3}^{+}$have also been discussed (Betts and Leigh, 1950), but have not given definite data probably because of experimental difficulty. According to spectro-photometrical data of the uranous chloride solution at a low $\mathrm{pH}$ range studied by $\mathrm{T}$. Tsuboya of Atomic Fuel Corporation, an absorption peak different from that of $\mathrm{UOH}^{3+}$ appeared at about $670 \mathrm{~m} \mu$ under $\mathrm{pH}$ about 1.5 and became equal in intensity with the latter when $\mathrm{pH}$ was about 2.0. This seems to suggest the appearance of a more hydrated species. In still higher $\mathrm{pH}$ regions it is well known that hydrated uranous ions are polymerized, like other actinide elements, with the rate of polymerization increasing with concentration and $\mathrm{pH}$ (Kraus et al., 1949). A complex of a uranous ion with chlorine, $\mathrm{UCl}^{3+}$, was reported to have the formation constant of 7.0 at $25^{\circ} \mathrm{C}$ (Kraus \& Nelson, 1950). Thus,

$$
\log \left[\mathrm{UCl}^{3+}\right]=\log \left[\mathrm{U}^{4+}\right]+\log \left[\mathrm{Cl}^{-}\right]+0.85
$$

Sexivalent uranium also forms hydrated uranyl ions except in acidic solutions. Although many forms of the hydrated ions such as $\left(\mathrm{UO}_{2}\right)_{2}(\mathrm{OH})^{9+}$, $\left(\mathrm{UO}_{2}\right)_{2}(\mathrm{OH})_{2}^{2+}$ and $\left(\mathrm{UO}_{2}\right)_{2}(\mathrm{OH})_{4}^{2+}$, have been suggested to exist in solutions (Dunsmore et al., 1963), only well established species; $\mathrm{UO}_{2} \mathrm{OH}^{+}$and $\mathrm{HUO}_{4}^{-}$(Hostetler \& Garrels, 1962) were considered in this study. This will not cause a serious error in calculating the 
equilibrium constants of the dissolution reactions of the uranyl minerals, as inferred from a fairly good coincidence of the experimental values of the solubility of uranyl hydroxide with the thermochemically calculated values by assuming only $\mathrm{UO}^{2+}$ and $\mathrm{UO}_{2} \mathrm{OH}^{+}$in solutions of $\mathrm{pH}$ below 6 according to the relation,

$$
\mathrm{UO}_{2}^{2+}+\mathrm{H}_{2} \mathrm{O}=\mathrm{UO}_{2} \mathrm{OH}^{+}+\mathrm{H}^{+}
$$

further reaction as follows being neglected in this case,

$$
\mathrm{UO}_{2} \mathrm{OH}^{+}+\mathrm{H}_{2} \mathrm{O}=\mathrm{HUO}_{4}^{-}+2 \mathrm{H}^{+}
$$

Many complexes of sexivalent uránium have been known (Harrington \& Ruehle, 1954). The chloride ion has been found to form a weak complex with uranyl, $\mathrm{UO}_{2} \mathrm{Cl}^{+}$. Nelson and Kraus (1951) gave the formation constant of 2.4 at $25^{\circ} \mathrm{C}$, while Ahrland (1951) gave 0.8 . The former value was adopted in this study. Thus,

$$
\log \left[\mathrm{UO}_{2} \mathrm{Cl}^{+}\right]=\log \left[\mathrm{UO}_{2}^{2+}\right]+\log \left[\mathrm{Cl}^{-}\right]+0.38
$$

It should be mentioned that the carbonate ion forms very stable uranyl complexes, and hence most of uranium in natural waters under neutral or alkaline conditions is present in these forms as examplified by the relations,

$$
\mathrm{UO}_{2}^{2+}+2 \mathrm{CO}_{3}^{2-}+2 \mathrm{H}_{2} \mathrm{O}=\mathrm{UO}_{2}\left(\mathrm{CO}_{3}\right)_{2} \cdot 2 \mathrm{H}_{2} \mathrm{O}^{2-}
$$

and

$$
\mathrm{UO}_{2}^{2+}+3 \mathrm{CO}_{3}^{2-}=\mathrm{UO}_{2}\left(\mathrm{CO}_{3}\right)_{3}^{4-}
$$

Sulphate may also form uranyl complexes under acidic conditions if sulphate concentration is high (more than $10^{-2} \mathrm{M}$ ).

The equilibrium constant of a chemical reaction can be calculated by the following equation from standard free energy of the reaction $\Delta F_{r}^{0}$, which is derived from the sum of the standard free energies of formation of the products of the reaction by subtracting those of the reactants. Standard free energies of formation $\Delta F_{f}^{0}$ used in this study are listed in Table 1 together with the standard enthalpies of formation $\Delta H_{f}^{0}$. 
Now, we have the well-known relation,

$$
\Delta F_{r}^{0}=-R T \ln K
$$

where $R$ is the gas constant $\left(1.987 \mathrm{cal} \cdot \mathrm{deg}^{-1} \cdot \mathrm{mole}^{-1}\right)$ and $T$ the absolute temperature. From equation $(16)$ at $25^{\circ} \mathrm{C}$,

$$
\Delta F_{1}^{0}=-1.346 \log K_{25}(\mathrm{Kcal})
$$

For higher temperatures, the Van't Hoff equation can be applied,

$$
\frac{d(\ln K)}{d t}=\frac{\Delta H}{R T^{2}}
$$

Although $\Delta H_{f}^{0}$ varies appreciably with temperature, a constant value assigned to enthalpy does not seem to introduce any appreciable error in the present case, because the temperature range is comparatively narrow, from $25^{\circ}$ to $100^{\circ} \mathrm{C}$. Thus, upon integration and substitution for $R$ and $T$ for $100^{\circ} \mathrm{C}$,

$$
\log K_{100}=\log K_{25}+0.147 \Delta H(\mathrm{Kcal})
$$

For equations (5), (6), (7), (9), (11), (12), (14) and (15), the following relations are obtained by using equations (17) and (19) based on the $\Delta F_{f}^{0}$ and $\Delta H_{f}^{0}$ values listed in Table 1 :

$$
\begin{aligned}
& \log \left[\mathrm{H}_{2} \mathrm{PO}_{4}^{-}\right]-\log \left[\mathrm{H}_{8} \mathrm{PO}_{4}\right]=\mathrm{pH}-2.13(=\mathrm{pH}-2.59) \cdots \cdots \cdots \ldots(5-1) \text {, } \\
& \log \left[\mathrm{HPO}_{4}^{2-}\right]-\log \left[\mathrm{H}_{2} \mathrm{PO}_{4}^{-}\right]=\mathrm{pH}-7.18(=\mathrm{pH}-7.05) \cdots \cdots \cdots \cdots(6-1) \text {, } \\
& \log \left[\mathrm{PO}_{4}^{a-}\right]-\log \left[\mathrm{HPO}_{4}^{2-}\right]=\mathrm{pH}-12.02^{\circ}(=\mathrm{pH}-11.51) \cdots \cdots \cdots(7-1) \text {, } \\
& \log \left[\mathrm{UOH}^{s+}\right]-\log \left[\mathrm{U}^{4+}\right]=\mathrm{pH}-1.17(=\mathrm{pH}+0.44) \quad \cdots \cdots \cdots \cdots(9-1) \text {, }
\end{aligned}
$$

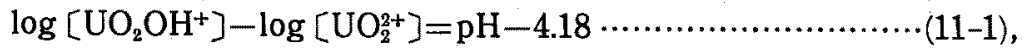

$$
\begin{aligned}
& \log \left[\mathrm{HUO}_{4}^{-}\right]-\log \left[\mathrm{UO}_{2} \mathrm{OH}^{+}\right]=2 \mathrm{pH}-19.43 \ldots \ldots \ldots \ldots \ldots \ldots \ldots \ldots \ldots \ldots \ldots \ldots \ldots(12-1) \text {, }
\end{aligned}
$$$$
\log \left[\mathrm{UO}_{2}\left(\mathrm{CO}_{3}\right)_{2} \cdot 2 \mathrm{H}_{2} \mathrm{O}^{2-}\right]-\log \left[\mathrm{UO}_{3}^{2+}\right]=2 \log \left[\mathrm{CO}_{3}^{2-}\right]+20.36 \cdots(14-1) \text {, }
$$

$$
\text { and } \log \left[\mathrm{UO}_{2}\left(\mathrm{CO}_{3}\right)_{3}^{4-}\right]-\log \left[\mathrm{UO}_{2}^{2+}\right]=3 \log \left[\mathrm{CO}_{3}^{2-}\right]+24.14 \cdots \cdots \cdots \cdots(15-1) \text {. }
$$

These are for equilibrium at $25^{\circ} \mathrm{C}$ but in parentheses at $100^{\circ} \mathrm{C}$. 


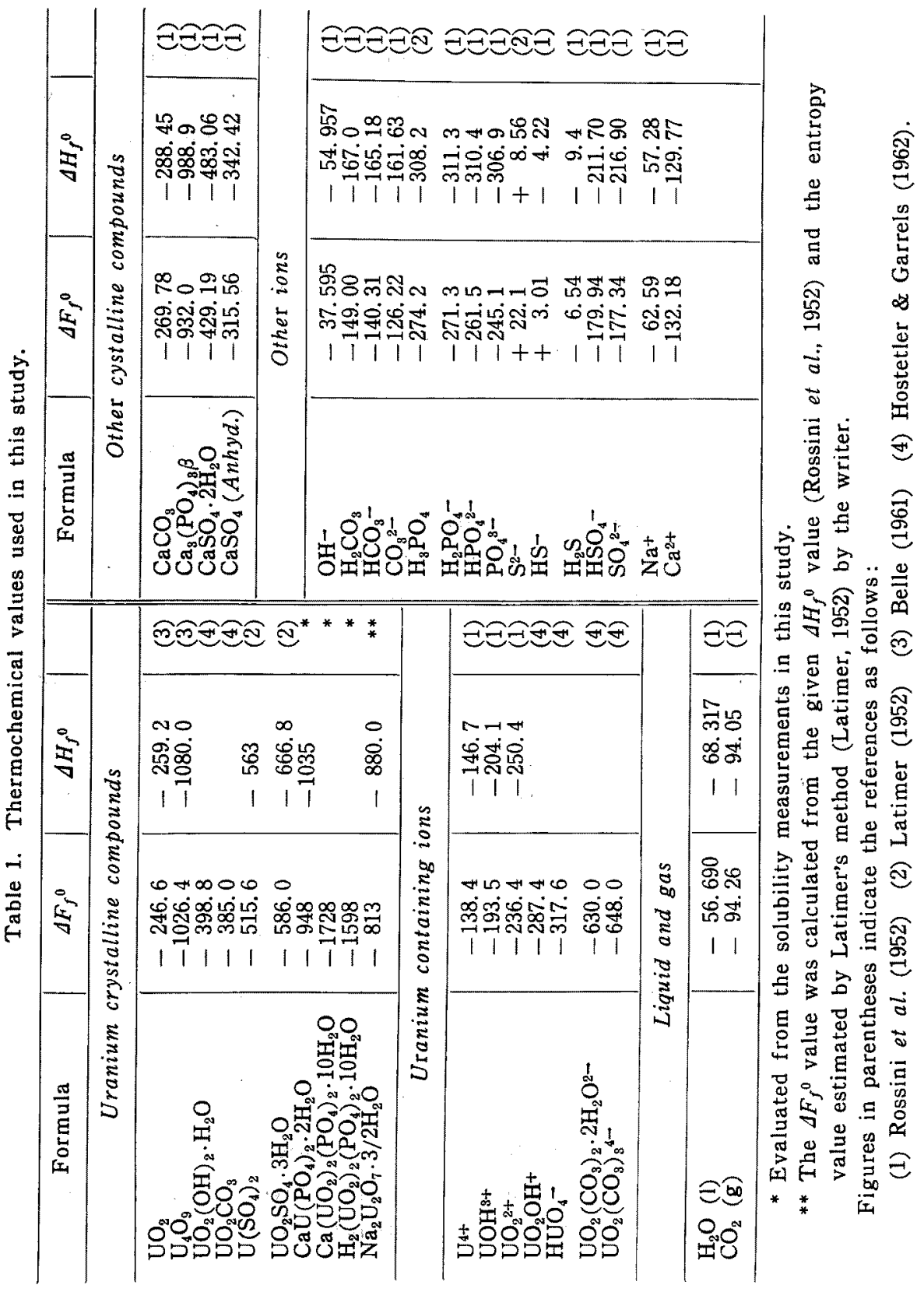


Calculation of $\Delta F_{f}^{0}$ and $\Delta H_{f}^{0}$ values

In the dissolution reactions of the minerals, concentrations of total phosphate and calcium, denoted by $\Sigma\left(\mathrm{PO}_{4}^{3-}\right)$ and $\left(\mathrm{Ca}^{2+}\right)$ respectively, are known from the analyzed total concentrations of uranium, $\Sigma(\mathrm{U}(\mathrm{IV}))$ or $\Sigma(\mathrm{U}(\mathrm{VI}))$, namely

$$
\begin{aligned}
& \text { from }(2) \quad \Sigma(\mathrm{U}(\mathrm{IV}))=\left(\mathrm{Ca}^{2+}\right)=\frac{1}{2} \Sigma\left(\mathrm{PO}_{4}^{3-}\right) \cdots \cdots \cdots \cdot(2-2), \\
& \text { from }(3) \quad \Sigma(\mathrm{U}(\mathrm{VI}))=2\left(\mathrm{Ca}^{2+}\right)=\Sigma\left(\mathrm{PO}_{4}^{3-}\right) \ldots \ldots \ldots \ldots(3-2) \text {, }
\end{aligned}
$$

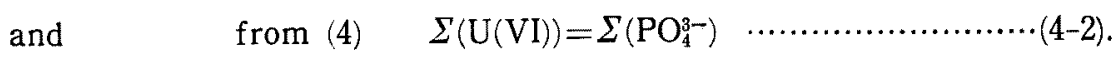

With the assumption that activity coefficients are the same throughout ionic species of phosphate, the ratios among $\left(\mathrm{H}_{8} \mathrm{PO}_{4}\right)$, $\left(\mathrm{H}_{2} \mathrm{PO}_{4}^{-}\right),\left(\mathrm{HPO}_{4}^{2-}\right)$ and $\left(\mathrm{PO}_{4}^{3-}\right)$ were calculated from equations (5-1), (6-1) and $(7-1)$ by employing measured $\mathrm{pH}$ values. $\left(\mathrm{HPO}_{4}^{2-}\right)$ and $\left(\mathrm{PO}_{4}^{8-}\right)$ were then found to be negligible in the $\mathrm{pH}$ range of the experiment. The $\mathrm{UO}_{2} \mathrm{H}_{2} \mathrm{PO}_{4}^{+}$complex ion may also take part in the total phosphate in the case of the uranyl minerals, and the ratio of $\left(\mathrm{UO}_{2} \mathrm{H}_{2} \mathrm{PO}_{4}^{+}\right)$to $\left(\mathrm{H}_{3} \mathrm{PO}_{4}\right)$ is calculated by equation (8). Thus, for the dissolution of ningyoite at $25^{\circ} \mathrm{C}$ (at $100^{\circ} \mathrm{C}$ ),

$$
\left(\mathrm{H}_{8} \mathrm{PO}_{4}\right)=2 \Sigma(\mathrm{U}(\mathrm{IV})) /\left(1+\frac{10^{-2.18}}{\left(\mathrm{H}^{+}\right)}\right)\left(=2 \Sigma(\mathrm{U}(\mathrm{IV})) /\left(1+\frac{10^{-2.69}}{\left(\mathrm{H}^{+}\right)}\right)\right) \cdots(20),
$$

and for those of autunite and $\mathrm{H}$-autunite at $25^{\circ} \mathrm{C}$,

$$
\left(\mathrm{H}_{8} \mathrm{PO}_{4}\right)=\Sigma(\mathrm{U}(\mathrm{VI})) /\left(1+\frac{10^{-2.13}}{\left(\mathrm{H}^{+}\right)}+\frac{10^{1.19}\left(\mathrm{UO}_{2}^{2+}\right)}{\left(\mathrm{H}^{+}\right)}\right) \cdots \cdots \cdots(21) .
$$

The concentration of $\mathrm{U}^{4+}$ was calculated similarly by equations (10) and (9-1) both for $25^{\circ} \mathrm{C}$,

$$
\left(\mathrm{U}^{4+}\right)=\Sigma(\mathrm{U}(\mathrm{IV})) /\left(1+\frac{10^{-1.17}}{\left(\mathrm{H}^{+}\right)}+10^{0.85}\left(\mathrm{Cl}^{-}\right)\right) \cdots \cdots \cdots \cdots \cdots(22)
$$

The concentration of $\mathrm{UCl}^{3+}$ may become neglegible at higher temperatures, if the $\mathrm{pH}$ of the solution is perhaps above 0.8 and $\mathrm{UOH}^{2+}$ is predominant instead of $\mathrm{U}^{4+}$ even when $\mathrm{pH}$ is 0 . Thus, at $100^{\circ} \mathrm{C}$ holds the relation, 


$$
\left(\mathrm{U}^{4+}\right)=\Sigma(\mathrm{U}(\mathrm{IV})) /\left(1+\frac{10^{+0.44}}{\left(\mathrm{H}^{+}\right)}\right)
$$

Similarly for the concentration of $\mathrm{UO}_{2}^{2+}$ to be derived from equations (8), (13) and (11-1), since $\mathrm{HUO}_{4}^{-}$is substantially lacking in neutral or acidic solutions,

$$
\left(\mathrm{UO}_{2}^{2+}\right)=\Sigma(\mathrm{U}(\mathrm{VI})) /\left(1+\frac{10^{-4.18}}{\left(\mathrm{H}^{+}\right)}+\frac{10^{1.19}\left(\mathrm{H}_{3} \mathrm{PO}_{4}\right)}{\left(\mathrm{H}^{+}\right)}+10^{0.38}\left(\mathrm{Cl}^{-}\right)\right) \cdots(23) .
$$

Concentrations of $\mathrm{H}_{3} \mathrm{PO}_{4}, \mathrm{U}^{4+}$ and $\mathrm{UO}_{2}^{2+}$ are calculated by equations (20), (21), (22) and (23), where $\mathrm{pH}, \Sigma(\mathrm{U}(\mathrm{IV}))$ or $\Sigma(\mathrm{U}(\mathrm{VI}))$ and $\left(\mathrm{Cl}^{-}\right)$are known experimentally.

The activity coefficient of each ion can be obtained by applying the Debye-Hückel limiting theory. A simple empirical equation which provides a good representation of the behavior of electrolytes up to the ionic strength of 0.2 (Robinson \& Stokes, 1959) was used in this study to estimate the coefficients, namely,

$$
\log \gamma_{i}=-\frac{A Z_{i}^{2} \sqrt{I}}{I+\sqrt{I}}+0.1 I
$$

where $A$ is a constant related with the absolute temperature and the dielectric constant of the solvent, and $I$ the iodic strength of the solution. In the case of an aqueous solution, $A$ is 0.5115 at $25^{\circ} \mathrm{C}$ and 0.6086 at $100^{\circ} \mathrm{C}$ (Robinson \& Stokes, 1959). I is given by,

$$
I=\frac{1}{2} \Sigma C_{i} Z_{i}^{2}
$$

where $C_{i}$ is the concentration of the $i$ ion and $Z_{i}$ its charge.

The $\Delta F_{f}^{0}$ and $\Delta H_{f}^{0}$ values of the three minerals were calculated by equations (17) and (19) from the equilibrium constants of their dissolution reaction. Data for the calculations are shown in Table 2. Experimental results under low $\mathrm{pH}$ are not listed as the activity coefficients cannot precisely be estimated and the results of ningyoite at higher $\mathrm{pH}$ are also omitted because the unknown ionic species discussed before were revealed in the solutions. From the mean $\Delta F^{0}$ values shown in Table $2, \Delta F_{f}^{0}$ values are calculated as follows; 


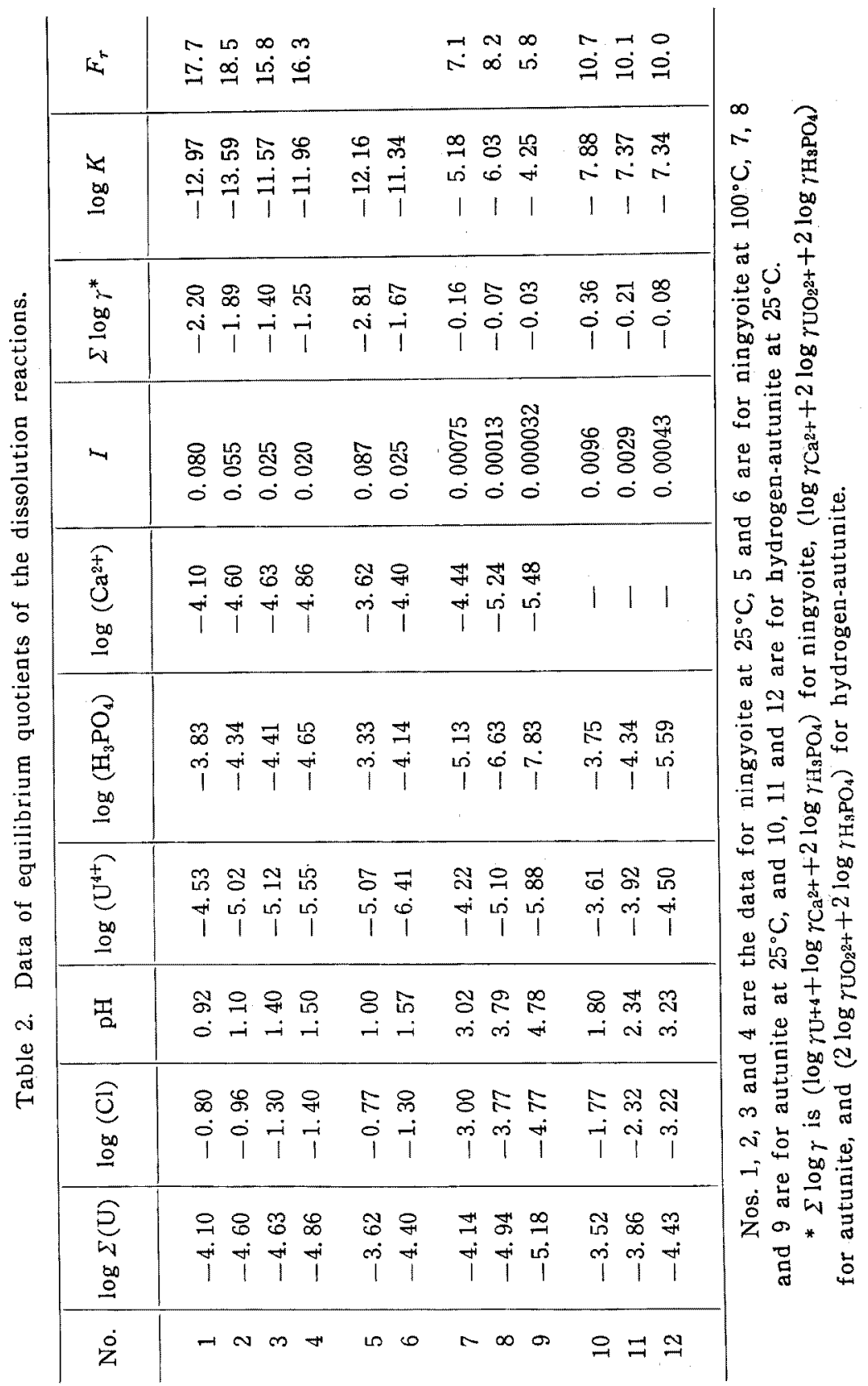




$$
\begin{aligned}
& \Delta F_{\text {ningyoite }}^{0}=\Delta F_{\mathrm{Ca}_{2}+}^{0}+\Delta F_{\mathrm{U}^{4+}}^{0}+2 \Delta F_{\mathrm{H}_{3} \mathrm{PO}_{4}}^{0}+2 \Delta F_{\mathrm{H}_{2} \mathrm{O}}^{0}-17.1=-949.4 \mathrm{Kcal}, \\
& \Delta F_{\text {autunite }}^{0}=\Delta F_{\mathrm{Ca}_{2} 2+}^{0}+2 \Delta F_{\mathrm{UO}_{2}{ }^{2+}}^{0}+2 \Delta F_{\mathrm{H}_{3} \mathrm{PO}_{4}}^{0}+10 \Delta F_{\mathrm{H}_{2} \mathrm{O}}^{0}-7.4=-1727.7 \mathrm{Kcal},
\end{aligned}
$$
and

$$
\Delta F_{\mathrm{H} \text {-autunite }}^{0}=2 \Delta F_{\mathrm{UO}_{2}{ }^{2+}}^{0}+2 \Delta F_{\mathrm{H}_{3} \mathrm{PO}_{4}}^{0}+10 \Delta F_{\mathrm{H}_{2} \mathrm{O}}^{0}-10.3=-1598.4 \mathrm{Kcal} \text {. }
$$

The $\Delta H_{f}^{0}$ of ningyoite is calculated by equation (19) to be $5.3 \mathrm{Kcal}$. Thus,

$$
\Delta H_{\text {ningyoite }}^{0}=\Delta H_{\mathrm{C}_{4} 2+}^{0}+\Delta H_{\mathrm{U}^{4}+}^{0}+2 \Delta H_{\mathrm{ri3}_{3} \mathrm{FO}_{4}}^{0}+2 \Delta H_{\mathrm{H}_{2} \mathrm{O}}^{0}-5.3=1034.8 \mathrm{Kcal} \text {. }
$$

The same procedures as above were also carried out for synthetic ningyoite samples: Cup-E2-150, Cup-E3-150, and Aup-D-130. The $\Delta F_{f}^{0}$ values obtained were $-950.3,-949.2$, and $-947.0 \mathrm{Kcal}$, respectively. This means that the differences in the chemical composition are in parallel with the change of the $\Delta F_{f}^{0}$ values. Aup-D-130 sample which was synthesized from apatite with a uranous phosphate slurry (Muto, 1962), is the most similar among the three to natural ningyoite, Cup-E3-150 resembles to the latter only in the ratio of calcium to uranium, and Cup-E2-150 has almost the ideal composition of $\mathrm{CaU}$ $\left(\mathrm{PO}_{4}\right)_{2} \cdot 2 \mathrm{H}_{2} \mathrm{O}$. Thus, an intermediate value between those of Aup-D130 and Cup-E3-150, namely $-948 \mathrm{Kcal}$, was adopted in this study.

The $\Delta F_{f}^{0}$ values of autunite and $\mathrm{H}$-autunite were also estimated from precipitation experiments, i.e., reactions reverse to dissolution. Both minerals were precipitated from solutions containing the stoichiometric amounts of uranium, phosphoric acid, and calcium. After 15 to 40 days, the $\mathrm{pH}$ 's of the residual solutions were measured and then analyzed for calcium, uranium and phosphorus. The $\Delta F_{f}^{0}$ values of autunite and $\mathrm{H}$-autunite were found to be -1726.8 and $-1596.7 \mathrm{Kcal}$ respectively. The values adopted in this study are $-1728 \mathrm{Kcal}$ for autunite and $-1598 \mathrm{Kcal}$ for $\mathrm{H}$-autunite. These values of the three minerals were estimated to have errors of $\pm 2 \mathrm{Kcal}$ for $\Delta F_{f}^{0}$ and $\pm 5 \mathrm{Kcal}$ for $\Delta H_{f}^{0}$.

Theoretical solubility curves of the minerals expressed in activity are shown in Fig. 1 together with the plots of the experimental values. Departures of the experimental values from the theoretical 
curves at the low $\mathrm{pH}$ region are explained by the decrease of activity coefficients due to increasing salt contents and also by the increase of formation of uranium complexes. The experimental values of ningyoite begin to divert from the theoretical curve at $\mathrm{pH}$ about 1.5. This seems to be caused by more hydrated uranous ions such as $\mathrm{U}(\mathrm{OH})_{2}^{2+}$, because this coincides well with the above mentioned experimental result of photo-spectrometry, namely, the appearance of a new peak at $\mathrm{pH}$ about 1.5 .

\section{Stability field of ningyoite}

Various phase diagrams can be constructed from the equilibrium relations in appropriate chemical equations when thermochemical data on the relating compounds and ions are known. In order to estimate the stability relations of ningyoite with the relating minerals, diagrams shown in Figs. 2, 3, 4, 5, 6 and 7 were constructed by using the thermochemical values obtained in the above together with those of the relating compounds and ions available as listed in Table 2.

\section{Eh-pH diagrams}

Some Eh-pH diagrams were produced in order to obtain a rough idea on the relations among ningyoite, the relating minerals, and the coexisting ions as shown in Figs. 2, 3, 4 and 5. The following two basic equations for the Eh-pH relation were used together with equation (17),

$$
E_{r}^{0}=\frac{\Delta F_{i}^{0}}{n \mathscr{F}}
$$

and

$$
E \mathrm{~h}=E_{r}^{0}+\frac{R T}{n \mathscr{I}} \ln Q
$$

where $E_{r}^{0}$ is the standard potential, $n$ is the number of electrons involved, $F$ is the faraday constant, and $Q$ is the reaction quotient in terms of activities. Full discussion of the procedure to obtain the Eh-pH diagram was given by Garrels (1960). All the Eh-pH diagrams in the figures of this paper are at $25^{\circ} \mathrm{C}$ and under 1 atmosphere. 
Fig. 2 is the Eh-pH diagram of the $\mathrm{U}-\mathrm{O}_{2}-\mathrm{H}_{2} \mathrm{O}$ system, where three solid phases, $\mathrm{UO}_{2}(\mathrm{OH})_{2} \cdot \mathrm{H}_{2} \mathrm{O}, \mathrm{U}_{4} \mathrm{O}_{9}$ and $\mathrm{UO}_{2}$ appear. The first compound was called schoepite by the calculaters of its $\Delta F_{f}^{0}$ value (Hostetler \& Garrels, 1962), but this name is better to be reserved, since becquerelite, masuyite, epi-ianthinite and schoepite have nearly the same chemical composition (Frondel, 1958). $\mathrm{U}_{4} \mathrm{O}_{9}$ is a compound having the $\alpha-\mathrm{UO}_{2}$ structure with a regular arrangement of excess

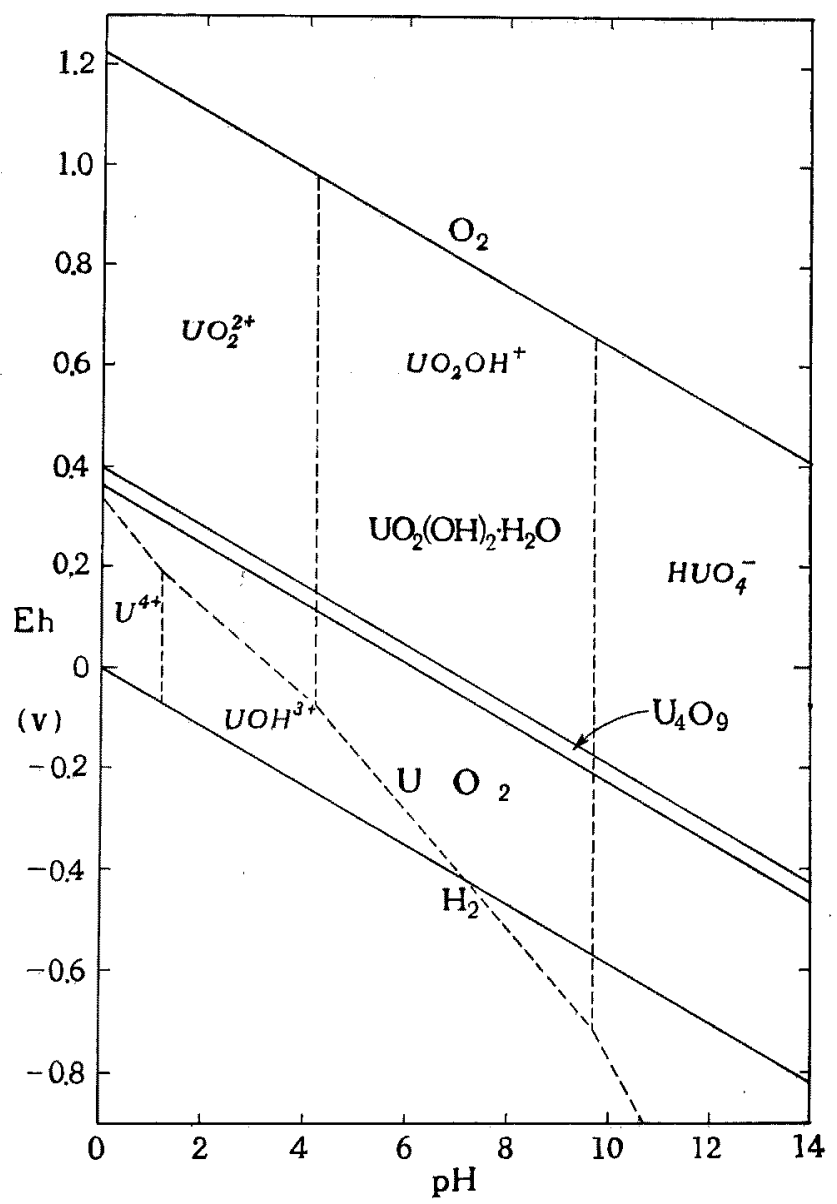

Fig. 2. Eh-pH diagram of $\mathrm{U}-\mathrm{O}_{2}-\mathrm{H}_{2} \mathrm{O}$ system. 
interstitial oxygen (Belle, 1961) and may be regarded at least thermochemically as a kind of uraninite called pitchblende $\mathrm{UO}_{2+x}, x$ usually ranging between 0.2 and 0.6 , though the regular arrangement of the excess oxygen has not been observed yet in uraninite. It can be seen from the figure that the tetravalent uranium can reduce $\mathrm{H}_{2} \mathrm{O}$ and evolve $\mathrm{H}_{2}$ under $\mathrm{pH}$ above 7 . This may not happen actually, though the uranous ion is known to be more easily oxidized in alkaline solutions than in acidic ones. Some correction will be needed for this point when thermochemical data are obtained of the unknown hydrated uranous ions mentioned above.

Sulphur and sodium are added to the system together with carbon dioxide and the results are shown in Fig. 3 . When the solution is in equilibrium with carbon dioxide in air $\left(\mathrm{P}_{\mathrm{CO}_{2}}=10^{-3.4} \mathrm{~atm}\right.$.), rutherfordine $\mathrm{UO}_{2} \mathrm{CO}_{3}$ takes the place of schoepite. Uranous and uranyl sulphates appear in the acidic side. Uranyl sulphate minerals occur in nature all with hydroxyl ions with or without another cation such as zippeite $\mathrm{K}_{4}\left(\mathrm{UO}_{2}\right)_{6}\left(\mathrm{SO}_{4}\right)_{3}(\mathrm{OH})_{10} \cdot \mathrm{H}_{2} \mathrm{O}$ or uranopilite $\left(\mathrm{UO}_{2}\right)_{6}\left(\mathrm{SO}_{4}\right)(\mathrm{OH})_{10}$. $12 \mathrm{H}_{2} \mathrm{O}$, while a uranous sulphate mineral has not been known yet. It is doubtful whether a uranium sulphide can exist stably in an aqueous solution, though in dry systems some sulphide have been synthesized. Various uranate compounds precipitates in strongly alkaline solutions, as shown here as sodium diuranate. Some uranate minerals such as wölsendorfite $(\mathrm{Pb}, \mathrm{Ca}) \mathrm{U}_{2} \mathrm{O}_{7} \cdot 2 \mathrm{H}_{2} \mathrm{O}$ have been known in nature. Uranyl carbonate complexes as shown in (14) and (15) predominate in $\mathrm{pH}$ above 6.1 .

By adding calcium and phosphorus to the system, Fig. 4 and 5 were obtained. The conditions concerning calcium and phosphorus in Fig. 4 corresponds to those of comparatively low salinity of rivers and lakes, and in Fig. 5 to those of comparatively high salinity of these and common closed basins and mineral springs, as will be discussed later. It is found in Fig. 4 and 5 that phosphate minerals appear under neutral and acidic conditions but not from alkaline solutions. Autunite can precipitate before schoepite or rutherfordine 


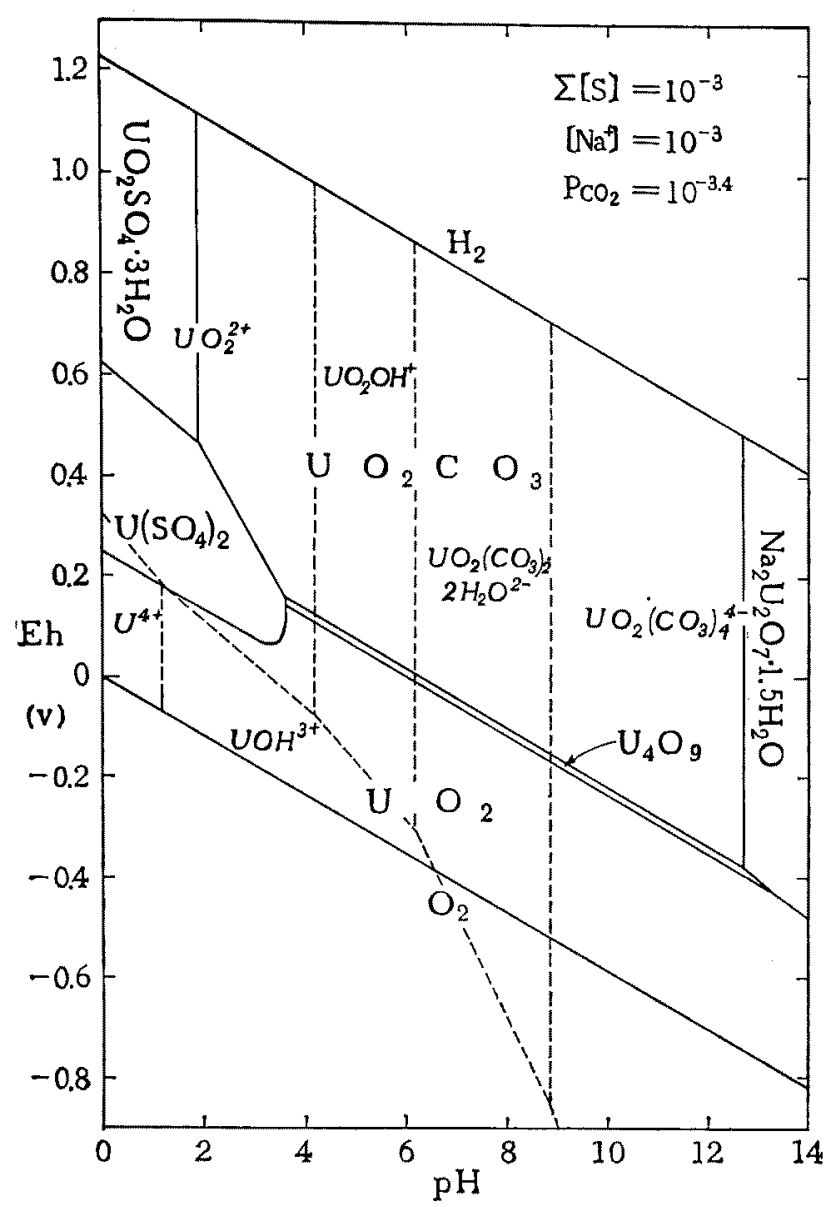

Fig. 3. Eh-pH diagram of $\mathrm{U}-\mathrm{O}_{2}-\mathrm{H}_{2} \mathrm{O}-\left(\mathrm{Na}-\mathrm{S}-\mathrm{CO}_{2}\right)$.

even if the phosphorus concentration is very low, while ningyoite cannot unless the concentration is considerably high. Frequencies of their occurrence in nature are thus explained from the above stability relations. Rarity of $\mathrm{H}$-autunite in nature may be explained from the fact that it grows only in an acidic solution.

Concentrations of phosphorus and calcium in natural waters are restricted by the solubility product of apatite. If thermochemical 


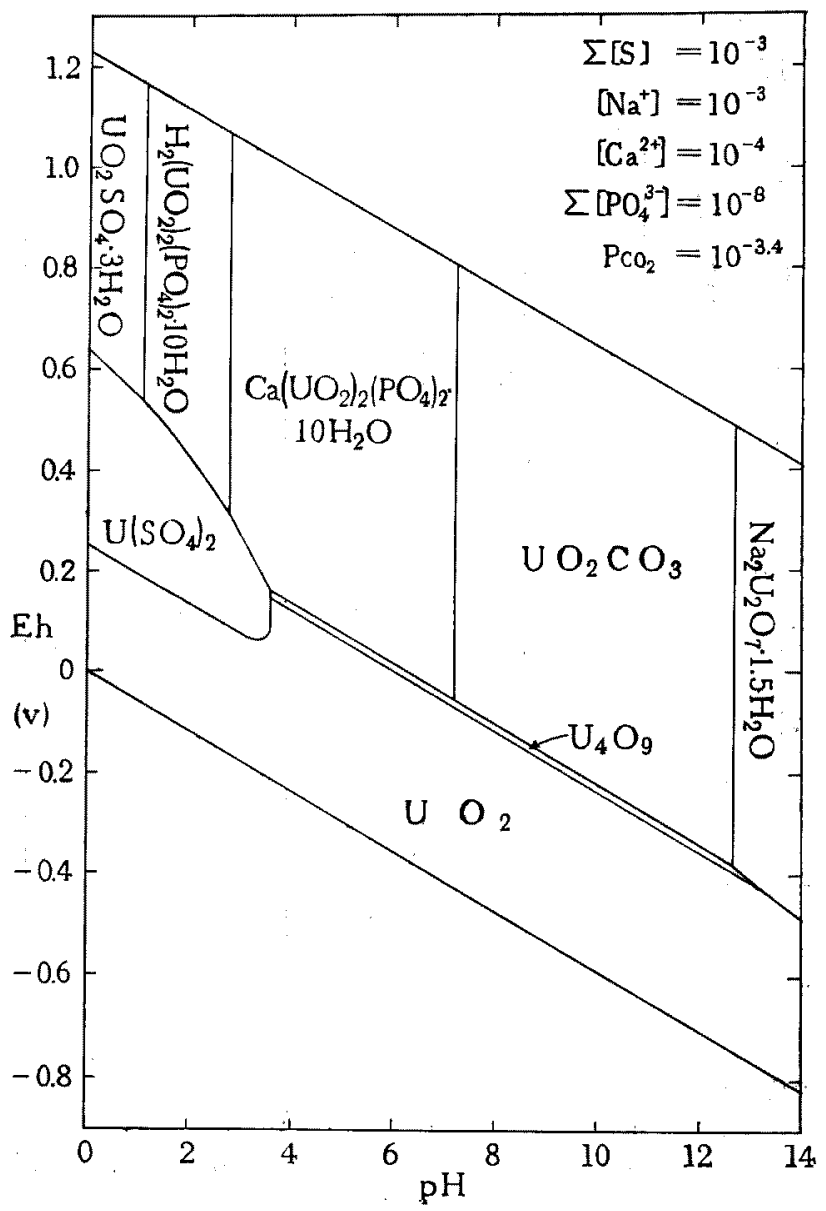

Fig. 4. Eh-pH diagram $\mathrm{I}$ of $\mathrm{U}-\mathrm{O}_{2}-\mathrm{H}_{2} \mathrm{O}-\left(\mathrm{Na}-\mathrm{S}-\mathrm{CO}_{2}-\mathrm{Ca}-\mathrm{P}\right)$.

data of $\beta \mathrm{Ca}_{8}\left(\mathrm{PO}_{4}\right)_{2}$ is used instead of apatite whose $\Delta F_{f}^{0}$ value has not been known,

$$
\mathrm{Ca}_{8}\left(\mathrm{PO}_{4}\right)_{2}=3 \mathrm{Ca}^{2+}+2 \mathrm{PO}_{4}^{3-}
$$

and

$$
3 \log \left[\mathrm{Ca}^{2+}\right]+2 \log \left[\mathrm{PO}_{4}^{3-}\right]=-33.14(-35.23)
$$

Phosphorus concentration must be lowered in an alkaline solution as understood from (28-1) together with (5-1), (6-1) and (7-1). Actual 


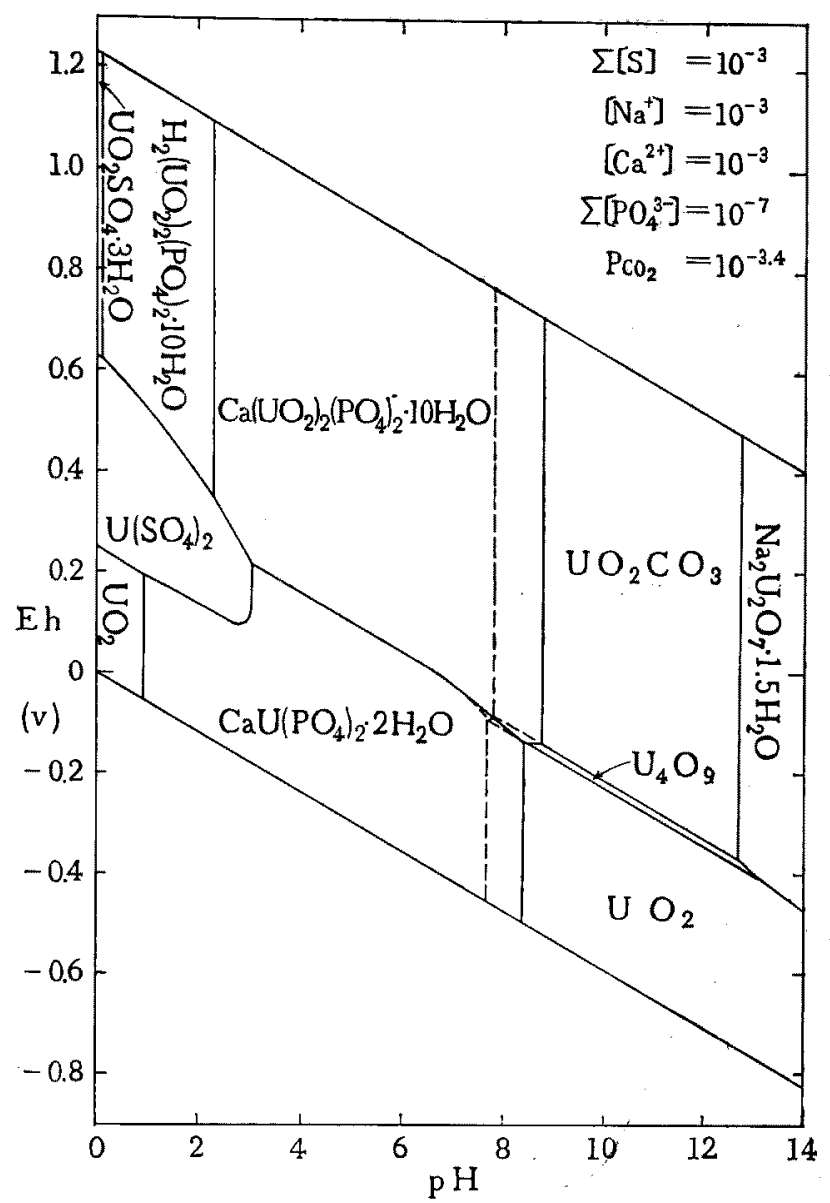

Fig. 5. Eh-pH diagram II of $\mathrm{U}-\mathrm{O}_{2}-\mathrm{H}_{2} \mathrm{O}-\left(\mathrm{Na}-\mathrm{S}-\mathrm{CO}_{2}-\mathrm{Ca}-\mathrm{P}\right)$.

The broken lines indicate the case where the total phosphorus concentration is limited by the solubility product of $\mathrm{Ca}_{3}$ $\left(\mathrm{PO}_{4}\right)_{2}$ in an alkaline solution.

boundaries of the phosphate minerals with other minerals in the alkaline part in Fig. 5 should be such as shown there by broken lines.

Stability of ningyoite in comparison with uraninite

There have been known in the epigenetic stratiform deposits only 
three primary uranium minerals uraninite, coffinite, and ningyoite. Among them, uraninite occurs most widely and abundantly in almost all uranium deposits, and its superior stability and extreme easiness of precipitation from solutions under reduced conditions are often demonstrated in the chemical experiments on uranium. In view of the ubiquity of uraninite, therefore, the stability of ningyoite or the environment of its precipitation can best be discussed by taking uraninite as a standard, where favourable conditions for coffinite $\mathrm{U}\left(\mathrm{SiO}_{4}\right)_{1-x}(\mathrm{OH})_{4 x}$ are supposed to be similar with those for the precipitation of silica.

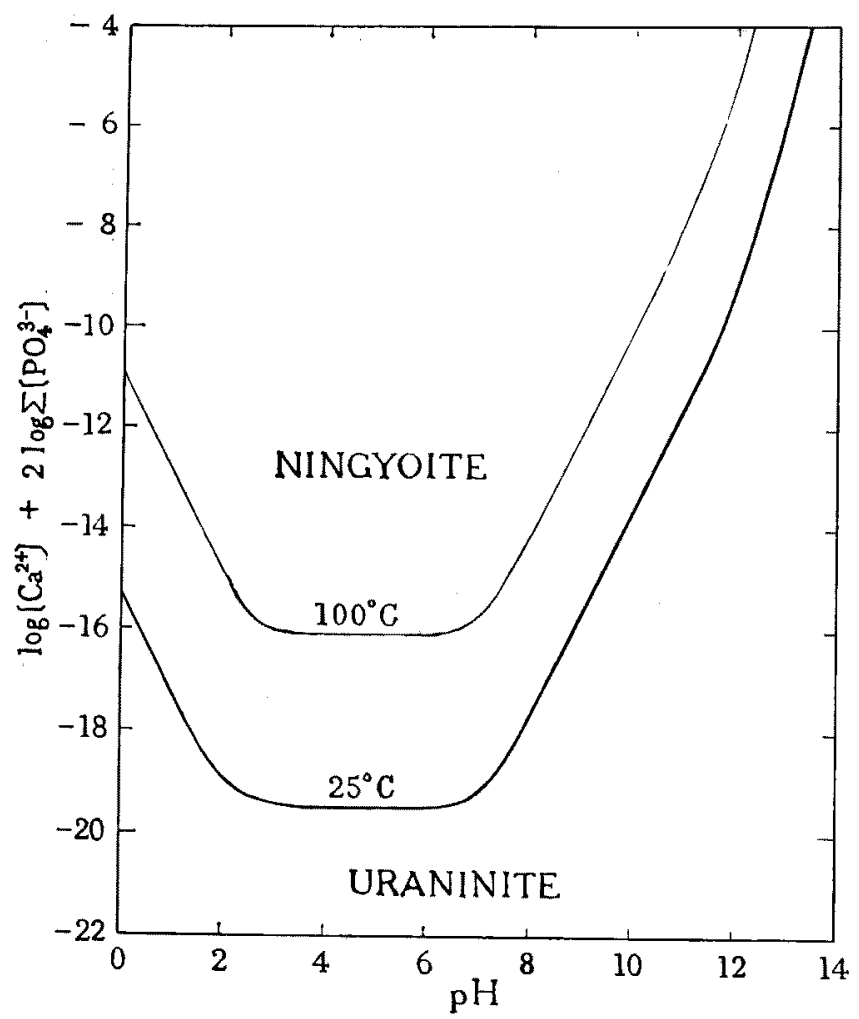

Fig. 6. Stability field of ningyoite with respect to calcium and phosphorus concentrations. 
Fig. 6 shows stability fields of uraninite and ningyoite with calcium and phosphorus concentrations combined as a parameter. The figure was constructed with the use of the following equations as well as $(5-1),(6-1)$ and $(7-1)$,

$$
\mathrm{CaU}\left(\mathrm{PO}_{4}\right)_{2} \cdot 2 \mathrm{H}_{2} \mathrm{O}=\mathrm{UO}_{2}+\mathrm{Ca}^{2+}+2 \mathrm{PO}_{4}^{3-}+4 \mathrm{H}^{+}
$$

and

$$
\log \left[\mathrm{Ca}^{2+}\right]+2 \log \left[\mathrm{PO}_{4}^{3-}\right]=4 \mathrm{pH}-57.9(4 \mathrm{pH}-52.2)
$$

It is found from the figure that ningyoite is stable under $\mathrm{pH}$ from about 3 to 6.5 and in the solutions in which $\log \left[\mathrm{Ca}^{2+}\right]+2 \log \Sigma\left[\mathrm{PO}_{4}^{3-}\right]$ exceeds -19.5 at $25^{\circ} \mathrm{C}$ and -16.1 at $100^{\circ} \mathrm{C}$.

Calcium concentrations of rivers and lakes are generally between $10^{-4}$ and $10^{-3} \mathrm{M}$ (Clarke, 1924). The average phosphorus concentration of them is not certain because the analyses have been done only for waters containing relatively high amounts of phosphorus, but most of the concentrations were estimated less than $10^{-7} \mathrm{M}$ (Rankama \& Sahama, 1950). The concentrations of the two elements in the water of mineral springs and closed basins are supposed to be roughly ten times higher than the above figures, though the values fluctuate considerably. The phosphorus in the water, however, is often contained in organic and inorganic colloids, especially in the case where the concentration is high, so that part or sometimes most of the phosphorus may not contribute to its activity. Therefore, it seems to be common for $\log \left[\mathrm{Ca}^{2+}\right]+2 \log \Sigma\left[\mathrm{PO}_{4}^{3-}\right]$ to exceed -19.5 at $25^{\circ} \mathrm{C}$, but not so common to exceed -16.1 at $100^{\circ} \mathrm{C}$ in nature, because higher phosphorus concentration may not be expected at higher temperatures as indicated for example from the solubility of $\mathrm{Ca}_{3}\left(\mathrm{PO}_{4}\right)_{2}$ shown in Fig. 7.

If the solubility product of apatite is taken into consideration and (28-1) is combined with (29-1), Fig. 7 is constructed. It can be understood from the figure that ningyoite very easily precipitate in acidic solutions saturated with apatite, while the upper $\mathrm{pH}$ limits of the precipitation are comparatively low especially at higher temperatures. The limits are evaluated from the figure as follows, 


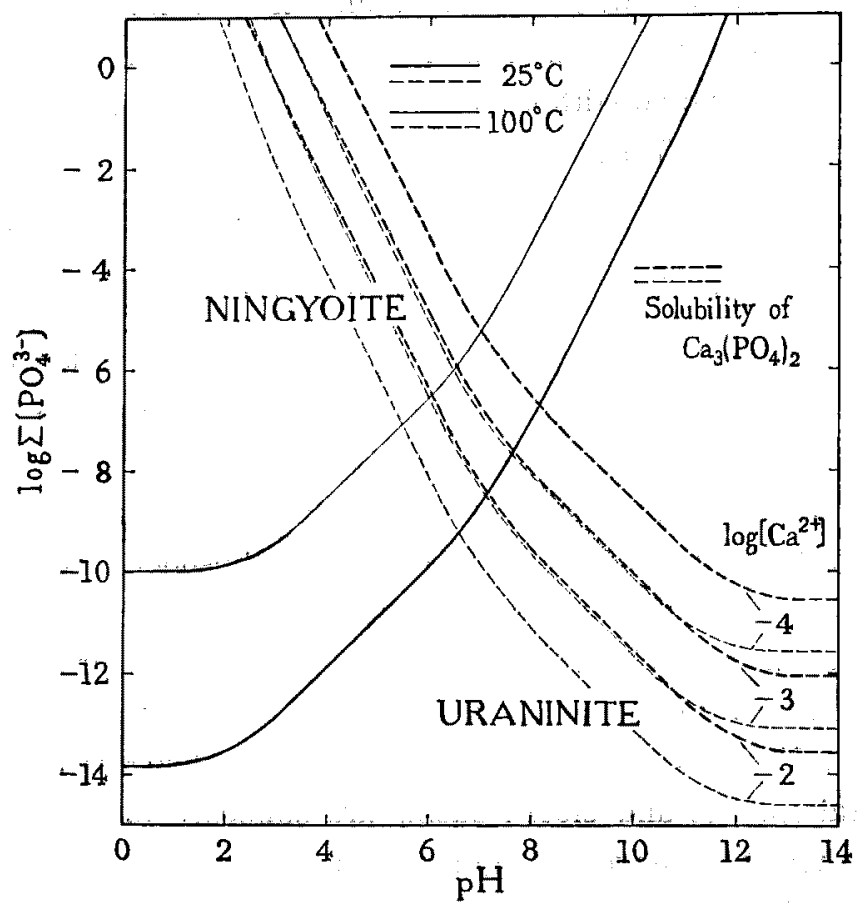

Fig. 7. Stability field of ningyoite in an aqueous solution saturated with apatite.

\begin{tabular}{|c|c|c|c|}
\hline $\log \left[\mathrm{Ca}^{2+}\right]$ & -4 & -3 & -2 \\
\hline $25^{\circ} \mathrm{C}$ & $8.2(-7.7)$ & $7.7(-8.2)$ & $7.2(-8.7)$ \\
\hline $100^{\circ} \mathrm{C}$ & $6.5(-6.1)$ & $6.0(-6.6)$ & $5.5(-7)$. \\
\hline
\end{tabular}

where figures in parentheses indicate $\log \Sigma\left[\mathrm{PO}_{4}^{s-}\right]$ necessary to form ningyoite at the given pH's.

Thus, it can be concluded from the above that ningyoite is formed rather easily under conditions from neutral to acidic at $25^{\circ} \mathrm{C}$, but not so at $100^{\circ} \mathrm{C}$, unless phosphorus concentration is unusually high in acidic solutions. 
Discussion in reference to natural modes of occurrence of ningyoite Occurrence of ningyoite around Ningyô-tôgé area

Properties of the solution from which some minerals have paragenetically precipitated may be estimated in some degree by thermochemical examinations of their mutual stability relations. The paragenetical combination of minerals observed in the unoxydized zone of the Asabatake ore body of the Tôgô mine, which is located in the north of the Ningyô-tôgé mine, is very instructive to estimate the properties of the ore solution, or more exactly of the solution from which uranium precipitated, in the uranium deposits around the Ningyố-tôgé area. Ningyoite is closely associated there with uraninite together with gypsum from anhydrite, calcite, and apatite as a relict mineral (Muto, 1962). The following chemical equations should then hold together with equations (26) and (27):

$$
\begin{aligned}
& \mathrm{CaSO}_{4}=\mathrm{Ca}^{2+}+\mathrm{SO}_{4}^{2-} \\
& \log \left[\mathrm{Ca}^{2+}\right]+\log \left[\mathrm{SO}_{4}^{2-}\right]=-4.61 \quad(=-5.05) \\
& \mathrm{CaCO}_{3}=\mathrm{Ca}^{2+}+\mathrm{CO}_{3}^{2-} \ldots \ldots \ldots \ldots \ldots \ldots \ldots \ldots \ldots \ldots \ldots \ldots \ldots \ldots \ldots \ldots \ldots \ldots \ldots \ldots \ldots \ldots \ldots \ldots
\end{aligned}
$$

and

$$
\log \left[\mathrm{Ca}^{2+}\right]+\log \left[\mathrm{CO}_{3}^{2-}\right]=-8.34(=-8.77)
$$

where, equation $(30-1)$ is for gypsum at $25^{\circ} \mathrm{C}$, but for anhydrite at $100^{\circ} \mathrm{C}$, as the former is stable below $42^{\circ} \mathrm{C}$ in a saturated solution of $\mathrm{CaSO}_{4}$ (Ponsjak, 1940). Acid constants of carbonate ions are calculated from Table 1 and following equations are obtained:

$$
\begin{aligned}
& \log \left[\mathrm{CO}_{3}^{2-}\right]-\log \left[\mathrm{HCO}_{3}^{-}\right]=\mathrm{pH}-10.33(=\mathrm{pH}-9.81) \\
& \log \left[\mathrm{HCO}_{3}^{-}\right]-\log \left[\mathrm{H}_{2} \mathrm{CO}_{3}\right]=\mathrm{pH}-6.37(=\mathrm{pH}-6.10)
\end{aligned}
$$

and $\quad \log \left[\mathrm{H}_{2} \mathrm{CO}_{3}\right]-\log P_{\mathrm{CO}_{2}}=-1.43(=-2.11)$

From equations (28-1), (29-1), (30-1) and (31-1) modified by (5-1), (6-1), $(7-1),(32),(33)$ and $(34)$,

$$
\log \left[\mathrm{Ca}^{2+}\right]=-2 \mathrm{pH}+12.40(=-2 \mathrm{pH}+8.98)
$$




$$
\begin{aligned}
& \log \left[\mathrm{SO}_{4}^{2-}\right]=2 \mathrm{pH}-17.01(=2 \mathrm{pH}-14.03) \quad \cdots \ldots \ldots \ldots \ldots \ldots \ldots(36) \text {, } \\
& \log \left[\mathrm{HCO}_{3}^{-}\right]=\mathrm{pH}-10.41(=\mathrm{pH}-7.94) \quad \cdots \ldots \ldots \ldots \ldots \ldots \ldots(37-1) \text {, } \\
& \log \left[\mathrm{H}_{2} \mathrm{CO}_{3}\right]=-4.04(=-1.84) \quad \cdots \cdots \cdots \cdots \cdots \cdots \cdots \cdots \cdots \cdots \cdots \cdots \cdots \cdots \cdots \cdots \cdots \cdots \cdots(37-2) \text {, }
\end{aligned}
$$

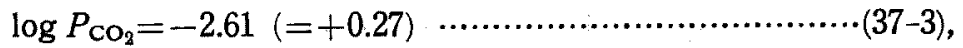

$$
\begin{aligned}
& \log \left[\mathrm{HPO}_{4}^{2-}\right]=2 \mathrm{pH}-23.13(=2 \mathrm{pH}-19.57) \quad \cdots \ldots \ldots \ldots \ldots(38-1) \text {, }
\end{aligned}
$$

and $\quad \log \left[\mathrm{H}_{2} \mathrm{PO}_{4}^{-}\right]=\mathrm{pH}-15.95(=\mathrm{pH}-12.52)$

The calcium concentration may be reasonably estimated as between $10^{-2}$ and $10^{-3} \mathrm{M}$ from the analytical data stated above. Then, the $\mathrm{pH}$

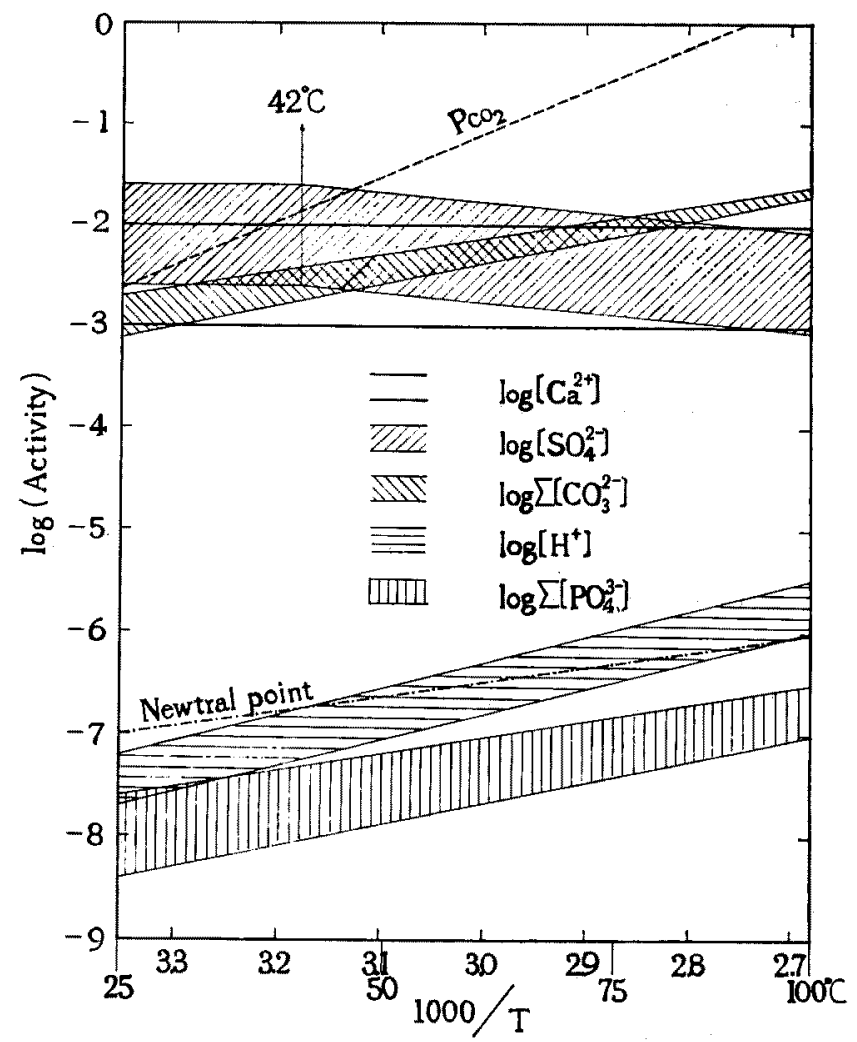

Fig. 8. Probable activities of the relating ions in the solution in equilibrium with ningyoite, uraninite, gypsum, calcite, and apatite. 
and concentrations of each ion may be given as follows : $7.2(5.5)<\mathrm{pH}<$ $7.7(6.0) ;-2.6(-3.1)<\log \left[\mathrm{SO}_{4}^{--}\right]<-1.6(-2.1) ;-3.1(-1.7)<\log \Sigma$ $\left[\mathrm{CO}_{3}^{2-}\right]<-2.7(1.6) ;-8.4(-7.0)<\log \Sigma\left[\mathrm{PO}_{4}^{3-}\right]<-7.6(-6.5)$. The values of $\log \Sigma\left[\mathrm{CO}_{3}^{2-}\right]$ and of $\log \Sigma\left[\mathrm{PO}_{4}^{s-}\right]$ are the sum of $\left[\mathrm{HCO}_{3}^{-}\right]$ and $\left[\mathrm{H}_{2} \mathrm{CO}_{3}\right]$ and that of $\left[\mathrm{HPO}_{4}^{--}\right]$and $\left[\mathrm{H}_{2} \mathrm{PO}_{4}^{-}\right]$respectively, as only these ions exist in the above $\mathrm{pH}$ region. The above values are expressed diagramatically in Fig. 8. It should be noted in the figure that phosphorus concentration is not high except at higher temperatures, $\mathrm{pH}$ indicates nearly neutral with a tendency to be slightly alkaline at lower temperatures and acidic at higher temperatures, and carbonate exists in a considerable amount especially at higher temperatures, while the necessary amount of sulphate ions decreases with increasing temperatures.

Conditions are somewhat different in the Ningyô-tôgé mine, where uraninite is commonly deficient concordantly with the lack of calcite and apatite (Muto, 1962). This may not indicate, as apatite is lacking, less carbonate and more phosphorus in the "solution" than in the case of the Asabatake ore body, but may indicate a lowering of the $\mathrm{pH}$ value or of the temperature of formation. Either of these two factors can eliminate uraninite, calcite, and apatite from the system. It has been suggested by the writer (Muto, 1962) from the comparison of the properties of ningyoite samples in both deposits that $\mathrm{pH}$ is lower in the former than in the latter. There is no other evidence to indicate a lower temperature of the formation in the former. Thus, it can be stated from the comparison with the probable $\mathrm{pH}$ in Asabatake, that the solution was weakly acidic in the Ningyô-tôgé uranium deposits, moderately or strongly acidic conditions being not expected, because kaolinite, which is rather stable in acidic solutions (Hemley, 1959; Muto, 1962), increases generally with the decrease of the uranium content in the ores in the Tôgé (Muto, 1961) and the Nakatsugô (Suginohara \& Okuno, 1964) ore bodies of the mine.

The weakly acidic condition of the "solution" in the Ningyô-tôgé 
deposits inferred in the above is inconsistent with part of the conclusion of the writer's previous paper, where he suggested weakly alkaline "solution" from the existence of corroded quartz grains and also from the comparison of natural ningyoite samples with synthetic ones, although the rest of the conclusion is in conformity with the results of the thermochemical estimation. Corroded quartz grains, however, have been found in later observations to occur only in the vicinities of faults where montmorillonitizations are remarkable, so that they do not necessarily indicate the alkaline "solution". The second reason for the suggestion of alkaline "solution" is not conclusive either because of the great difference in the Ca to $U$ ratio of the solution between nature and the experiment.

Some zonal arrangement of uraninite, coffinite, and ningyoite have been reported by Okuno (1964) in the Kannokura ore deposits of the Tôgô mine. The center of each deposit which is localized in each palaeostream channel is mainly mineralized by uraninite or coefficite or both, and surrounded by a ningyoite zone, though coffinite occurs only in silicified woods. It may be difficult to explain this occurrence based on a mechanism of precipitation of uranium from laterally or downwards moving water, because centers of the channels cannot be expected to have been higher in $\mathrm{pH}$ than the surroundings. The occurrence may be elucidated by supposing that ascending water carrying uranium which was higher in temperature or in $\mathrm{pH}$ than waters filling the channels, came up along some fissures of the basement localized at the uraninite zone, whether the ascending water was hypogenic or not. This presumption is reasonable as inferred from the fact that some veins mineralized with ningyoite have been found in the base granite just under the Nakatsugô ore body, although the ascending waters in these veins might be comparatively low in $\mathrm{pH}$ or in temperature.

Rarity of Ningyoite

The reason why ningyoite has never been found in the other 
uranium deposits may be explained by the above mentioned two factors; $\mathrm{pH}$ and temperature. The formation of ningyoite from hydrothermal solutions seems to be improbable unless the solution is unusually rich in the phosphorus concentration under an acidic condition. Most of the epigenetic stratiform deposits in sedimentary rocks are considered to have been formed under weakly alkaline conditions and often under thick overburdening strata which would raise the temperature of formation up to $100^{\circ} \mathrm{C}$ or more. The condition is again not favorable for the formation.

There are so many uranium containing phosphorite beds in the world (Heinrich, 1958). But. no uranium mineral except secondary ones has been found in these and uranium is generally considered to be contained in apatite in a form of the cation U(IV) substituted for calcium (Clarke \& Altschuler, 1958), though several other mechanisms have also been proposed. Ningyoite is not expected in the phosphorite in spite of its extremely high phosphorus and calcium contents, because all the uraniferous phosphorite is of the marine origin (Heinrich, 1958). Sea water contains calcium of about $10^{-2} \mathrm{M}$, and then from Fig. 7, for the precipitation of ningyoite, $\mathrm{pH}$ should be less than 7.2 , which is significantly smaller than that of sea water.

\section{Acknowledgements}

This work was done in Atomic Fuel Research Lab., Tokai Refinery, Atomic Fuel Corporation. The writer is especially grateful to his colleagues, Dr. S. Hirono and Mr. H. Kurata in the laboratory for their aids in the experiments, and to Messrs. S. Takani and other members of the Refinery for chemical analyses.

\section{REFERENCES}

Ahrland, S. (1951). Acta Chem. Scand., 5, 1271-1282.

Belle, J. (1961). Uranium Dioxide, U.S. Govern. Print. Office.

Betts, R. H. \& Leigh, R. M. (1950). Canad. Jour. Res., 28, Sec. B, 514-525.

Clarke, F.W. (1924). U.S. Geol. Survey Bull., 770. 
Clarke, Jr. R.S. \& Altschuler, Z.S. (1958). Geochim. Cosmochim. Acta, 13, $127-142$.

Deitz, V.R., Rootare, H. M. \& Carpenter, F. G. (1964). J. Colloid Sci., 19, 87101.

Dunn, H. W. (1956). U.S. A. E.C. Rept., ORNL-2092.

Dunsmore, H.S., Hietanen, S. \& Sillén, L. G. (1963). Acta Chem. Scand., 17, 2644-2656.

Fisher, F. G. \& Meyrowitz, R. (1962). Amer. Min., 47, 1346-1355.

Frondel, C. (1958). U.S. Geol. Survey Bull., 1064.

Garrels, R. M. (1960). Mineral Equilibria, Harper and Brothers.

Harrington, C. D. \& Ruehle, A.E. (1959). Uranium Production Technology, $D$ van Nostrand.

Heinrich, E. Wm. (1958). Mineralogy and Geology of Radioactive Raw Materials, McGraw Hill.

Hemley, J. J. (1959). Amer. Jour. Sci., 257, 241-270.

Hostetler, P. B. \& Garrels, R. M. (1962). Econ. Geol., 57, 137-167.

Kraus, K. A. \& Nelson, F. (1950). J. Amer. Chem. Soc., 72, 3901-3906.

Kraus, K. A., Nelson, F. \& Johnson, G. L. (1949). J. Amer. Chem. Soc., 71, 2510-2517.

Latimer, W.M. (1952). Oxidation Potentials, 2nd ed., Prentice-Hall.

Muto, T. (1961). Min. Jour., 3, 195-222.

Muto, T. (1962). Min. Jour., 3, 306-337.

Nelson, F. \& Kraus, K. A. (1951). J. Amer. Chem. Soc., 73, 2157-2161.

Okuno, T. (1964). Submit. Ann. meeting, Atom. Energy Soc. Japan, G19.

Ponsjak, E. (1940). Amer. Jour. Sci., 238, 559-568.

Rankama, K. \& Sahama, T. G. (1950). Geochemistry, Univ. Chicago.

Robinson, R. A. \& Stokes, R.H. (1959). Electrolyte Solutions, 2nd ed., Butterworths.

Rossini, F. D. et al. (1952). Natl. Bur. Standards Circ. 500.

Suginohara, M. \& Okuno, T. (1964). Submit. Ann. Meeting, Atom. Energy Soc. Japan, G25.

Thamer, B. J. (1957). J. Amer. Chem. Soc,, 79, 4298-4305.

Manuscript received 27 September 1964. 